\title{
Bavarian AIDS case to to to highest West German court
}

Munich

THE next battle in the West German AIDS (acquired immune deficiency syndrome) controversy will be fought in West Germany's highest court, the Bundesverfassungsgericht, or federal constitutional court.

A 46-year-old United States citizen convicted by a Bavarian court of inflicting "grievous bodily harm" on three sexual partners by not informing them that he carried the AIDS virus is now appealing, giving the Bundesverfassungsgericht its chance to join the fray.

The controversy, which has raged since the federal election in January that returned a conservative/liberal coalition to power, pits Health Minister Rita Süssmuth (Christian Democrat) and others against her coalition partners in Bavaria, the Christian Social Union (see Nature 325, 650; 1987 and 327, 264; 1987).

A decision handed down by the Landgericht Nuremberg-Fürth on 16 November sentenced the defendant, who has been in custody since February, to two years in prison. The prosecution had asked for a sentence of three and a half years. The case is seen as a landmark in deciding the legal liability of a human immunodeficiency virus (HIV) carrier who does not inform sexual partners of his or her condition.

The court called upon the West German government to add AIDS to the list of notifiable diseases, which already includes syphilis, gonorrhoea and other sexually transmitted diseases. People who are diagnosed with these diseases and who refuse to be treated for them must be reported to health authorities by name. They can then be forced to undergo treatment.

Süssmuth and her allies in the Social Democrats and Greens, currently in the opposition, reject the call to make AIDS notifiable, as there is no known cure for the disease. A registration requirement would just drive HIV carriers underground, they argue. Bavarian state secretary Peter Gauweiler, who has led the Bavarian crusade against AIDS, supports the measure.

The defence in the Nuremberg case asked for an innocent verdict, on the grounds that the defendant's sexual partners knew the risks of having sexual relations in the age of AIDS. But the court ruled that HIV carriers have a responsibility not to pass on the virus. Even though the defendant used a condom during ejaculation in all three cases, some risk remained.

The court ruled that even this "residual risk" should not burden an unwitting sexual partner. A HIV carrier should practise "safe sex [i.e. use a condom during the entire sex act] or no sex at all", announced the court. In none of the cases could it be proved that the partner had

been infected with the virus.

Wilfully spreading AIDS can already be punished under West German law with enforced "isolation", although no case has as yet gone that far. Bavaria is the only Land to have expressed an intention to apply this law to HIV carriers who behave in an "unreasonable" way, such as prostitutes who do not use condoms.

Steven Dickman

\section{New mirror furnace takes first spin}

Tucson, Arizona

MIRror builders at the University of Arizona Steward Observatory fired up their massive rotating furnace for its first mirrorcasting test on 9 November. This first attempt will produce a $1.2-\mathrm{m}$ parabolic mirror intended for a Smithsonian Institution telescope at Mount Hopkins, south of Tucson, but the new furnace will eventually be expanded to accommodate $6.5-\mathrm{m}$ and 8-m mirrors.

Spin-casting mirrors - as the technique developed by the Arizona astronomer J. Roger P. Angel is called - promises to revolutionize mirror production. When the 5-m mirror in the Palomar Observatory's Hale telescope was made in 1948, it took a year to cool and was much heavier than spin-cast mirrors will be. The spin-cast mirrors will need far less extensive grinding and polishing and will cool in only about four weeks.

To start the process, $450 \mathrm{lb}$ of glass was heated to $1,180^{\circ} \mathrm{C}$ by 3,000 feet of electric heating coils in the oven's walls, floor and lid. When the temperature reached $900^{\circ} \mathrm{C}$, the 23-ton steel turntable began rotating the furnace 8.5 times per minute for almost

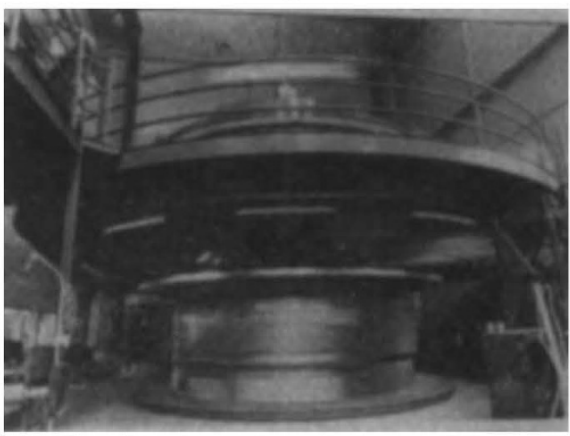

Rotating furnace

15 hours to spread the glass over its mould and into a 1.2-m diameter parabolic shape.

This mirror is the third produced by spin-cast technology. If it is successful, the mirror laboratory plans to make two $3.5-\mathrm{m}$ mirrors.
Elizabeth Pennisi

\section{Call for government re-think on radiation dose limits in Britain}

\section{London}

THE British government seems likely to amend its present radiation dose limits following advice* from the National Radiological Protection Board (NRPB) based on information from a preliminary reassessment of fatal cancer in the survivors of the atomic bombs at Hiroshima and Nagasaki.

In September, the International Commission on Radiological Protection (ICRP) concluded that the results of the Japanese study raised the risk estimate for the exposed population approximately twofold. The ICRP decided against immediately recommending a change in dose limits, and will not issue new advice until it has completed a review, likely to take at least two years. Pre-empting any advice from the ICRF, the NRPB is recommending an annual dose equivalent limit of 15 millisieverts for radiation workers and $0.5 \mathrm{mSv}$ for members of the public (the present limits are $50 \mathrm{mSv}$ and $1 \mathrm{mSv}$, respectively).

Re-evaluation of the Japanese data means that risk associated with continu- ous exposure at the occupational dose limit of $50 \mathrm{mSv}$ per year has increased from 1 in 2,000 per year to about 1 in 700 per year - a level of risk that "verges on the unacceptable", according to Roger Clarke, NRPB's director. About 2,000 people work near the dose limit -1 per cent of workers whose exposure to radiation is monitored.

For members of the public, continued exposure at $1 \mathrm{mSv}$ per year gives a risk of 1 in 100,000 per year on the old risk estimates and 3 in 100,000 per year on the new risk estimates - again verging on the unacceptable.

The board's criteria for 'acceptability' are based on the results of a Royal Society study group report on risk assessment, published in 1983. The Health and Safety Commission, one of the agencies with a regulatory responsibility, immediately announced its intention to re-examine radiation control measures in the light of the NRPB's advice. Simon Hadlington

"NRPB-GS9. Interim Guidance on the Implications of Recen Revisions of Risk Estimates and the ICRP 1987 Como State ment. (HMSO, £3.00.) 